\title{
Analiza i ocena wpływu wzrostu kwoty wolnej od podatku na kondycję finansową organizacji ze statusem pożytku publicznego
}

\author{
AgATA LEWANDOWSKA \\ mgr, Uniwersytet Szczeciński, Wydział Zarządzania i Ekonomiki Usług \\ e-mail: alewandowska.expo@gmail.com
}

SŁoWA KLUCZOWE organizacje pozarządowe, organizacje pożytku publicznego, kwota wolna od podatku, podatek dochodowy od osób fizycznych

StreszCZENIE

Cel - artykuł jest próbą ukazania wpływu prognozowanego zwiększenia kwoty wolnej od podatku na kondycję organizacji pozarządowych ze statusem pożytku publicznego. W artykule podjęto zagadnienia związane z genezą zjawiska wspólnotowości i filantropii, początków systemu polityki społecznej, z powstaniem i funkcjonowaniem organizacji pozarządowych w Polsce oraz organizacji non profit posiadających status organizacji pożytku publicznego. Przybliżono pojęcie ekonomii społecznej oraz scharakteryzowano najczęściej powstające w Polsce typy organizacji pozarządowych. W kolejnych akapitach przedstawiono sytuację finansową i uwarunkowania działania organizacji III sektora, ze szczególnym uwzględnieniem sposobu funkcjonowania organizacji pozarządowych posiadających statut organizacji pożytku publicznego.

Metodyka badania - analiza porównawcza, wnioskowanie logiczne.

Wynik - próba analizy i oceny wpływu wzrostu kwoty wolnej od podatku na działalność organizacji posiadających status OPP.

Wartość - w artykule przeanalizowano proponowane zmiany wysokości kwoty wolnej od podatku i jej możliwy wpływ na sytuację organizacji ze statusem organizacji pożytku publicznego w Polsce. Zmiany opisano i oceniono na tle wcześniejszych regulacji. Analiza wskazuje na problemy z implementacją oraz interpretacją niektórych zapisów i trudności w stosowaniu wprowadzanych przepisów z powodu ich niedostosowania i niejednoznaczności.

\section{The analysis and evaluation of the impact of tax-free growth on the financial condition of non-governmental organizations with the public benefit organization status}

KEYWORDS non-governmental organizations, non-governmental organizations having the status of public benefit organizations, tax allowance, personal income tax

ABSTRACT Purpose - the article is to indicate the impact of the projected increase in the amount of tax-free on the condition of non-governmental organizations having public-utility status. This paper presents issues related to origin of the phenomenon of community and philanthropy, social policy system, the emergence and functioning of non-governmental organizations in Poland and non-profit organizations with the status of public benefit organizations. The concept of social economy was approximated and the types of non-governmental organizations most commonly found in Poland were characterized. 
The following paragraphs outline the financial situation and determinants of the organization of the 3rd sector, with particular reference to the way NGOs operate with statutes of public benefit organizations.

Methodology - comparative analysis, logical reasoning.

Findings -This article is an attempt to analyse and assess the impact of an increase in the amount of tax-free on the activities of organizations with OPP status.

Value - The article analyzes the proposed changes to the amount of tax-free and its possible impact on the situation of organizations having the status of public benefit organizations in Poland. The changes have been described and evaluated against the background of previous regulations. The analysis points to problems with the implementation and interpretation of some of the provisions and difficulties in applying the provisions because of their maladjustment and ambiguity.

\section{Wprowadzenie}

Niepodważalny wpływ na stabilność finansów publicznych mają podatki, jako jedno z najważniejszych źródeł dochodu budżetu państwa. Z szacunków Ministerstwa Finansów wynika, że podwyższenie kwoty wolnej od podatku, do około 8 tys. zł, spowoduje zmniejszenie dochodów państwa o ponad 20 mld zł, przy jednoczesnym wzroście dochodów Polaków, pozwalającym na oszczędności w świadczeniach rodzinnych jedynie o ok. 0,4 mld zł. Podnoszenie kwoty wolnej od podatku bez jednoczesnego podnoszenia podatków, zmniejszania wydatków lub uszczelniania systemu ściągania podatków należnych prowadzi nieuchronnie do wzrostu deficytu budżetowego. Ekonomia społeczna jest traktowana przez Komisję Europejską, a także organy krajowe jako narzędzie aktywizacji społeczności lokalnych oraz walki z wykluczeniem społecznym, zwłaszcza w regionach słabszych ekonomicznie, zagrożonych ubóstwem. Wspiera proces budowania społeczeństwa obywatelskiego i pomaga rozwijać postawy obywatelskie. Jest jednym z priorytetów Unii Europejskiej w zakresie spójności społecznej, walki z bezrobociem, ubóstwem, nadmiernym zadłużeniem oraz biedą. Pozwala wykorzystywać zasoby ludzkie, których nie obejmuje sektor prywatny ani publiczny, zapobiega wykluczeniu społecznemu i łagodzi napięcia społeczne (Pieńkowska, 2015). Pojęcie ekonomii społecznej jest bardzo szerokie i obejmuje wiele sfer życia społecznego. Jej główną ideą jest prymat działania na rzecz ludzi (członków, podopiecznych) nad maksymalizacją zysku (Majchrzak, 2015, s. 70).

Celem artykułu jest ukazanie wpływu prognozowanego zwiększenia kwoty wolnej od podatku na kondycję organizacji pozarządowych ze statusem pożytku publicznego. Czy rząd - likwidując PIT i podnosząc kwotę wolną od podatku - przygotował jednocześnie propozycję innego sposobu przekazywania 1\% lub też finansowania organizacji pożytku publicznego? Artykuł jest próbą analizy i oceny wpływu wzrostu kwoty wolnej od podatku na kondycję finansową organizacji pożytku publicznego.

\section{Wspólnota, obywatelskość, filantropia - geneza i uwarunkowania}

Potrzeba wzajemnego wspierania się towarzyszyła ludziom od zawsze. Do czynników wyzwalających takie działanie zaliczyć należy m.in.: poszukiwanie jedzenia, schronienia, bezpieczeństwa, wsparcia emocjonalnego, czy biologicznej konieczności podtrzymywania gatunku. 
Od początku naszego istnienia zrzeszanie i gromadzenie się wokół wspólnej idei, sprawy czy zainteresowań było naturalnym, ludzkim odruchem. Już Arystoteles w Polityce (2001), podjął próbę zdefiniowania obywatela: jako osoby, która rządzi i jest rządzona jednocześnie a w swoim działaniu oraz decydowaniu kieruje się dobrem wspólnym, a nie własnym, ukazując potrzebę jednoczenia się, wzajemnej pomocy, wspierania i przekazywania dóbr innym, a więc postaw filantropijnych. Nad obywatelskością i społeczeństwem, istotą relacji między państwem a obywatelem rozważało wielu badaczy, począwszy od czasów starożytnych: Palton, wspomniany Arystoteles, św. Tomasz z Akwinu, Cyceron, czy bardziej współcześni - A. Smith, I. Kant czy K. Marks. Organizacje niezorientowane na zysk istnieją na całym świecie. Dobrze funkcjonują w krajach uprzemysłowionych i stanowią kluczowy element społeczeństw w gospodarkach rozwijających się. Ludzie pragną, by usługi zdrowotne, opieka społeczna, oświata, edukacja, pomoc humanitarna, działalność ekologiczna i kulturalna przyczyniały się do poprawy świata, w którym żyjemy. Oczekują, że organizacje świadczące takie usługi będą działały „nie dla zysku” jednocześnie nie należąc do sektora publicznego (Hudson, 1997, s. 10).

\section{Początki systemu polityki społecznej w Polsce}

Informacje o postawach filantropijnych można odnaleźć w piśmiennictwie polskim począwszy od średniowiecza - „we Wrocławiu, w 1108 roku, ufundowany został szpital przez lokalnych władców" (Leś, 2000, s. 36-37). Takie i tym podobne inicjatywy przyczyniły się do powstawania nieformalnych grup zadaniowych, które przez lata, ewoluowały w organizacje kastowe, religijne, prorządowe i wreszcie obywatelskie. W okresie międzywojennym, odzyskując niepodległość w 1918 roku, Polska odziedziczyła trzy różne systemy opieki społecznej. Dążąc do ich unifikacji powołano państwową (publiczną) służbę zatrudnienia oraz system opieki społecznej - miały one podlegać ówczesnemu Ministerstwu Pracy i Polityki Społecznej, Ministerstwu Zdrowia Publicznego i w części Ministerstwu Spraw Wewnętrznych. Dominującymi wyzwaniami była walka $\mathrm{z}$ analfabetyzmem oraz masowym bezrobociem. W Polsce lat 50 . XX wieku, w okresie tzw. realnego socjalizmu całkowicie negowano potrzebę istnienia instytucji pomocy społecznej. Przyjęto pogląd o bezcelowości tej strefy, deklarując likwidację zjawisk żebractwa i bezrobocia czy też bezdomności, ubóstwa i alkoholizmu. Zlikwidowano prywatne i społeczne pośrednictwo pracy, przekształcając je w komórki organizacyjne rad narodowych - zbyt zcentralizowane i przesiąknięte ideowością, by mogły realnie pomagać potrzebującym. Jednak to wówczas zawiązały się m.in.: Polski Komitet Pomocy Społecznej, Polski Czerwony Krzyż, Liga Kobiet (Gorlach, 1996). Obok nurtu oficjalnego należy wskazać także działalność opozycyjną - NSZZ „Solidarność” na sztandarach miała hasła pracowniczo-socjalne, odnoszące się bezpośrednio do sfery polityki społecznej (Piotrowski, 2010). Zapisy w konstytucji z 1952 roku wskazywały, że organizacje tworzono odgórnie, natomiast organizacje powstające po 1989 roku, które dodatkowo wzmocniła Konstytucja RP z 1997 roku, są już organizacjami z inicjatywy oddolnej. To właśnie okres zachodzących w Polsce przemian politycznych po 1989 roku, utorował drogę dynamicznemu rozwojowi organizacji samopomocowych, pozarządowych stowarzyszeń i fundacji, które jako III sektor gospodarki, wraz ze strefą biznesu i administracją publiczną tworzą współczesne społeczeństwo obywatelskie. Polski sektor pozarządowy kształtował się w okresie transformacji przede wszystkim pod wpływem dwóch głównych czynników 
sprawczych - charakterystycznego dla wielu ruchów społecznych i obywatelskich mechanizmu samorozwoju i samoedukacji oraz szeroko pojętej pomocy zagranicznej (Gliński, 2006, s. 31). Jednym z trzech podstawowych celów polskiej transformacji - oprócz wprowadzenia instytucji rynku i demokracji - był rozwój społeczeństwa obywatelskiego (Gliński, 2006, s. 7). Działalność organizacji pozarządowych regulowana jest wieloma przepisami. W Konstytucji, zgodnie z art. 12, czyli na poziomie najwyższym, zagwarantowane zostało prawo do zrzeszania się (odzwierciedlone także w Ustawie z 7 kwietnia 1989 roku Prawo o stowarzyszeniach (Dz.U. 1989, nr 20, poz. 104).

\subsection{Organizacje pozarządowe w Polsce - definicja}

Organizacje pozarządowe (NGO), niekomercyjne, non profit, III sektora to wszystkie podmioty, które nie są jednostkami albo organami administracji publicznej oraz których działalność nie jest nastawiona na osiąganie zysku. Prawną definicję organizacji pozarządowych w Polsce została sprecyzowana w Ustawie z 24 kwietnia 2003 roku o działalności pożytku publicznego i o wolontariacie. Ustawa wprowadza rozszerzoną definicję organizacji pozarządowych jako podmiotów prowadzących działalność pożytku publicznego, jako „działalność społecznie użyteczną, prowadzoną przez organizacje pozarządowe w sferze zadań publicznych określonych w ustawie" (Zgodnie z art. 3 Ustawy z dnia 24 kwietnia 2003 r. o działalności pożytku publicznego i o wolontariacie (Dz.U. 2014, poz. 1118) - szczegółowy zakres sfer działalności pożytku publicznego znajduje się w art. 4)). Właśnie społeczny wymiar działalności, oparty na zaangażowaniu dobrowolnym, pro publico bono oraz aktywność obywatelska to cechy charakterystyczne NGO, wśród których można wyróżnić, np. organizacje: samopomocowe, które swoją działalność wiążą ściśle z pomocą swoim członkom; opiekuńcze, zajmujące się wszystkimi potrzebującymi pomocy; przedstawicielskie, reprezentujące jakąś konkretną społeczność; mniejszości, działające na rzecz grup mniejszościowych różnego typu. Zakres i rodzaj ich działalności określone są w polskim prawie i dotyczą sfer działalności pożytku publicznego m.in.: wspierania rodziny, działalności na rzecz zatrudnienia, zdrowia, przedsiębiorczości, turystyki, edukacji, kultury, bezpieczeństwa, ochrony zwierząt i ludności, promocji wolontariatu, przeciwdziałaniu uzależnieniom, wspieraniu osób wykluczonych, rozwoju dzieci i młodzieży (Zgodnie z art. 3 Ustawy z 24.04.2003 r. o działalności pożytku publicznego i o wolontariacie, Dz.U. 2014, poz. 1118 szczegółowy zakres sfer działalności pożytku publicznego znajduje się w art. 4).

\subsection{Stowarzyszenia i fundacje}

Ustawa o działalności pożytku publicznego i o wolontariacie reguluje m.in. prowadzenie działalności pożytku publicznego oraz wskazuje jakie podmioty są organizacjami pozarządowymi. Szczegółowo definiuje je art. 3.1 ustawy (Dz.U. 2014, poz. 1118). Trzy najczęściej zakładane w Polsce typy organizacji to: stowarzyszenie zwykłe, stowarzyszenie rejestrowe i fundacja, co zaprezentowano w tabeli 1. 
Tabela 1. Podstawy prawne działania najczęściej zakładanych organizacji pozarządowych w Polsce

\begin{tabular}{|c|c|c|c|}
\hline Jednostka & Forma organizacyjna & Komitet założycielski & $\begin{array}{c}\text { Forma prawna/sposób rejestracji/ } \\
\text { forma działania }\end{array}$ \\
\hline 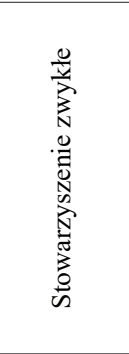 & $\begin{array}{l}\text { dobrowolne, samorządne, trwałe zrzeszenie } \\
\text { o celach niezarobkowych; może we } \\
\text { własnym imieniu nabywać prawa, zaciągać } \\
\text { zobowiązania, pozywać i być pozywane }\end{array}$ & 3 osoby & $\begin{array}{l}\text { złożenie wniosku o wpis do ewi- } \\
\text { dencji stowarzyszeń zwykłych wła- } \\
\text { ściwemu organowi nadzorującemu; } \\
\text { nie ma osobowości prawnej, nie } \\
\text { prowadzi działalności gospodarczej } \\
\text { i nie tworzy związków, nie może } \\
\text { powoływać terenowych jednostek } \\
\text { organizacyjnych, zrzeszać osób } \\
\text { prawnych, prowadzić odpłatnej } \\
\text { działalności pożytku publicznego }\end{array}$ \\
\hline  & $\begin{array}{l}\text { dobrowolny i trwały związek grupy osób, } \\
\text { powstały w celu realizowania wspólnych } \\
\text { zamierzeń; podstawą takiego związku } \\
\text { mogą być wspólne zainteresowania, } \\
\text { prowadzenie niezarobkowej działalności, } \\
\text { np. kulturalnej; stowarzyszenie określa } \\
\text { swój program i strukturę, w ramach której } \\
\text { działa; może być podmiotem gospodar- } \\
\text { czym z własną działalnością (jednak nie } \\
\text { może być ona dominująca), a ewentualne } \\
\text { dochody przeznacza na cele statutowe } \\
\end{array}$ & $\begin{array}{l}7 \text { osób - obywatele } \\
\text { polscy i cudzoziemcy } \\
\text { z miejscem zamiesz- } \\
\text { kania na terytorium } \\
\text { Polski lub zamieszku- } \\
\text { jący poza terytorium } \\
\text { Polski, jeśli statut } \\
\text { danego stowarzysze- } \\
\text { nia przewiduje taką } \\
\text { możliwość }\end{array}$ & $\begin{array}{l}\text { zobowiązane jest do uchwalenia } \\
\text { statutu, w którym określa zakres } \\
\text { działania i władze; ma osobowość } \\
\text { prawną z chwilą wpisania do KRS }\end{array}$ \\
\hline 丞 & $\begin{array}{l}\text { zajmuje się realizacją określonych zadań } \\
\text { pomocowych; zakres tych działań jest } \\
\text { określony w statucie fundacji, najczęściej } \\
\text { przez jej założyciela, który w tzw. akcie } \\
\text { fundacyjnym przekazuje pieniądze na } \\
\text { realizację jej celów; działalność fundacji } \\
\text { musi ograniczać się do zadań społecznych, } \\
\text { może prowadzić działalność gospodarczą } \\
\text { (jednak nie może być ona dominującą), } \\
\text { a ewentualne dochody przeznacza na cele } \\
\text { statutowe }\end{array}$ & $\begin{array}{l}\text { osoby fizyczne, } \\
\text { niezależnie od ich } \\
\text { obywatelstwa i miejsca } \\
\text { zamieszkania lub } \\
\text { osoby prawne z siedzi- } \\
\text { bami w Polsce lub za } \\
\text { granicą }\end{array}$ & $\begin{array}{l}\text { fundator ustala statut, nazwę, } \\
\text { siedzibę, majątek, cele, zasady, } \\
\text { formy, zakres działalności, skład } \\
\text { i organizację zarządu, itp.. (Ustawa } \\
\text { o fundacjach z } 6.04 .1984 \text { r., Dz.U. } \\
\text { 1984, nr } 21 \text { poz. 97); obowiązek } \\
\text { złożenia do KRS oświadczenia } \\
\text { woli o ustanowieniu fundacji } \\
\text { w formie aktu notarialnego wraz } \\
\text { z wymaganymi załącznikami; ma } \\
\text { osobowość prawną z chwilą wpisa- } \\
\text { nia do KRS }\end{array}$ \\
\hline
\end{tabular}

Źródło: opracowanie własne na podstawie ustawy o działalności pożytku publicznego i o wolontariacie.

\subsection{Uwarunkowania działania organizacji III sektora - sytuacja finansowa}

Teoria „dobra publicznego” głosi, że takie organizacje istnieją, ponieważ są ludzie, którzy widzą konieczność świadczenia usług publicznych wykraczających poza to, co władze są w stanie sfinansować z podatków. Władze ograniczają się do świadczenia tych usług, za które przeciętny wyborca jest skłonny płacić w formie podatków. Osoby, finansujące dodatkowe usługi publiczne, robią to dobrowolnie w formie darowizny (Hudson, 1997, s. 216).

We wszystkich organizacjach non profit za najważniejszy problem uznawane jest pozyskiwanie funduszy na działalność statutową i bieżącą. Trudności w zdobywaniu funduszy lub sprzętu deklaruje aż 65\% organizacji. W latach 2011-2014 przeciętne przychody organizacji 
pozarządowej wzrosły z 18 tys. zł do 27 tys. zł, co w głównej mierze spowodowane było napływem dotacji unijnych. Mimo poprawy sytuacji finansowej organizacji, sektor pozostaje budżetowo rozwarstwiony. Poważną przeszkodą w funkcjonowaniu organizacji jest duża niestabilność finansowa - na początku marca 2015 roku 51\% organizacji miało zapewnioną mniej niż połowę budżetu na kolejne 10 miesięcy (Adamiak, Charycka, Gumkowska, 2016, s. 14).

\section{Organizacje pożytku publicznego i status organizacji pożytku publicznego}

Należy odróżniać działalność pożytku publicznego od statusu organizacji pożytku publicznego (OPP). Działalność pożytku publicznego może być bowiem prowadzona nie tylko przez organizacje, które uzyskały status organizacji pożytku publicznego (Mucha, 2011, s. 13). Od 2004 roku organizacje pozarządowe mogą starać się o uzyskanie statutu organizacji pożytku publicznego. Nie ma znaczenia ich forma prawna, np.: stowarzyszenie, fundacja czy klub sportowy, warunkiem bezwzględnym jest jednak dysponowanie osobowością prawną oraz minimum dwuletni okres działania na rzecz odbiorcy zewnętrznego. Ponadto, aby dana organizacja uzyskała status OPP musi spełnić wszystkie wymogi ustawy (Ustawa o działalności pożytku publicznego i o wolontariacie, Dz.U. 2014, poz. 1118) i uzyskać potwierdzenie tego faktu przez odpowiedni wpis do KRS (na wyciągu z Krajowego Rejestru Sądowego, w polu „status opp” musi być wpisane słowo „TAK”). Organizacjom ze statusem OPP przysługują określone przywileje, ale też spełniać muszą wiele wymogów m.in.: mają prawo do zwolnienia z podatku VAT, podatku dochodowego, podatku od nieruchomości, opłat skarbowych czy sądowych, dotyczy to jedynie nieodpłatnej działalności pożytku publicznego. Do ich obowiązków należą m.in.: dostosowanie statutu do wymogów przewidzianych w ustawie, sporządzanie sprawozdań z działalności i obowiązek ich publikacji.

\subsection{Kto może przekazać $1 \%$ na rzecz OPP?}

Określenie grupy mogącej przekazać 1\% na rzecz OPP zostało sprecyzowane w ustawie (Art. 3. Ustawy z 26.07.1991 r. o podatku dochodowym od osób fizycznych, Dz.U. 1991, nr 80, poz. 350). Mogą to być rozliczający się w Polsce: podatnicy podatku dochodowego od osób fizycznych (w tym m.in. podatnicy uzyskujący dochody z odpłatnego zbycia papierów wartościowych Ustawa z 29.07.2005 r. o obrocie instrumentami finansowymi, Dz.U. 2005 nr 183 poz. 1538); podatnicy opodatkowani ryczałtem od przychodów ewidencjonowanych; podatnicy prowadzący jednoosobową działalność gospodarczą i korzystający z liniowej, 19\% stawki podatku; emeryci, pod warunkiem, że samodzielnie wypełnią PIT-37 i zrezygnują z pomocy ZUS w tym zakresie. 1\% nie mogą przekazywać osoby prawne, np. spółki, inne organizacje pozarządowe, przedsiębiorstwa państwowe, itp.; $1 \%$ nie jest darowizną ani ulgą. Z obywatelskiego punktu widzenia jest to przejaw demokracji bezpośredniej. W ten sposób społeczeństwo „asystuje” Ministrowi Finansów przy dystrybucji środków publicznych. Pieniądze otrzymane przez OPP, w ramach $1 \%$ mogą być wydane wyłącznie na prowadzenie działalności pożytku publicznego. Informację, na co zostały one spożytkowane, organizacja ze statusem pożytku publicznego ma obowiązek umieścić w swoim sprawozdaniu merytorycznym, fizycznie na dokumentach finansowo-księgowych oraz rzeczach materialnych sfinansowanych z 1\%, zgodnie ze wzorem 
określonym w rozporządzeniu Ministra Rodziny, Pracy i Polityki Społecznej (Ministerstwo Pracy i Polityki Społecznej, 2016).

Tabela 2. Źródła finansowania, z których korzystały organizacje pozarządowe w latach 2003-2014 (\%)

\begin{tabular}{|c|c|c|c|c|c|c|}
\hline Źródła finansowania & 2003 & 2005 & 2007 & 2009 & 2011 & 2014 \\
\hline Składki członkowskie & 60 & 60 & 57 & 61 & 61 & 60 \\
\hline Źródła samorządowe & 45 & 43 & 50 & 51 & 49 & 55 \\
\hline Darowizny od osób prywatnych & 41 & 36 & 36 & 37 & 28 & 45 \\
\hline Darowizny od instytucji i firm & 39 & 35 & 38 & 34 & 30 & 35 \\
\hline Przychody z przekazania $1 \%$ podatku & - & 6 & 13 & 17 & 17 & 23 \\
\hline Źródła rządowe & 19 & 20 & 22 & 23 & 12 & 18 \\
\hline Fundusze Unii Europejskiej & - & 3 & 7 & 9 & 12 & 18 \\
\hline Odsetki bankowe, zyski z kapitału żelaznego, udziały i akcje & 15 & 14 & 16 & 14 & 17 & 13 \\
\hline Odpłatna działalność statutowa & 8 & 9 & 10 & 10 & 9 & 11 \\
\hline Wsparcie krajowych organizacji pozarządowych & 9 & 7 & 7 & 10 & 9 & 11 \\
\hline Przychody ze zbiórek publicznych & 7 & 7 & 7 & 10 & 7 & 10 \\
\hline Działalność gospodarcza & 11 & 7 & 7 & 6 & 9 & 7 \\
\hline Inne źródła & 12 & 8 & 6 & 7 & 9 & 5 \\
\hline Zagraniczne źródła publiczne spoza UE & 4 & 3 & 6 & 5 & 2 & 4 \\
\hline Wsparcie zagranicznych organizacji pozarządowych & 5 & 4 & 4 & 3 & 3 & 4 \\
\hline Przychody, np. z wynajmu lokali, sprzętu & - & 3 & 4 & 4 & 2 & 4 \\
\hline Dotacje od oddziału tej samej organizacji & 3 & 5 & 2 & 3 & 2 & 2 \\
\hline Nawiązki sądowe & - & - & - & - & 1 & 1 \\
\hline
\end{tabular}

Źródło: Adamiak, Charycka, Gumkowska (2016), s. 65.

Na przykładzie danych zaprezentowanych w tabeli 2 widać, że przychód z 1\% dla organizacji pożytku publicznego nie jest podstawowym źródłem utrzymania, jednak z roku na rok przybywa organizacji mających przychody z tego właśnie źródła. Z uwagi na wieloletni proces informowania opinii publicznej wzrosła świadomość społeczna, a tym samym ilość funduszy wpływających z 1\% do budżetów tych organizacji. Wydaje się, że zjawisko to będzie charakteryzowała tendencja wzrostowa, co bezpośrednio wpłynie na różnorodność pomocy udzielanej przez takie organizacje społeczeństwu.

\section{Wpływ wzrostu kwoty wolnej od podatku na kondycję finansową organizacji pozarządowych ze statusem organizacji pożytku publicznego}

\subsection{Kwota wolna od podatku w Polsce i na świecie}

Kwota wolna od podatku w Polsce to 3091 zł (obowiązuje już kilka lat, a jest określona przez art. 27 ust. 1 Ustawy z 26.07.1991 r. o podatku dochodowym od osób fizycznych (Dz.U. z 1991 r., nr 80, poz. 350 ze zm.). We wszystkich krajach i w większości systemów podatkowych funkcjonuje kwota niepodlegająca opodatkowaniu. Wysokość tej kwoty w poszczególnych krajach jest bardzo różna. W Europie kwoty te kształtują się tak, jak przedstawiono w tabeli 3. 
Tabela 3. Kwota niepodlegająca opodatkowaniu w Europie (w wybranych krajach)

\begin{tabular}{|l|c|c|}
\hline \multicolumn{1}{|c|}{ Kraj } & $\begin{array}{c}\text { Kwota niepodlegająca opodatkowaniu } \\
\text { (euro) }\end{array}$ & $\begin{array}{c}\text { Procent średniej pensji } \\
\text { w danym kraju }\end{array}$ \\
\hline Polska & 738 & 6 \\
\hline Niemcy & 8130 & 20 \\
\hline Grecja & 5000 & 46 \\
\hline Francja & 5963 & 18 \\
\hline Hiszpania & 17707 & 73 \\
\hline Austria & 11000 & 32 \\
\hline Finlandia & 16100 & 40 \\
\hline Wielka Brytania & 12000 & 38 \\
\hline
\end{tabular}

Źródło: opracowanie własne na podstawie Raportu z Badań 2015 Stowarzyszenia Klon/Jawor.

W krajach takich jak: Maroko (z kwotą wolną od podatku w wysokości 11 tys. zł), Tajlandia (14 tys. zł), USA (ok. 38,5 tys. zł), Kolumbia (ok. 45 tys. zł) wychodzi się z założenia, że opodatkowywanie osób o najniższych dochodach jest bezcelowe - ściągane podatki i tak musiałyby do nich wrócić w postaci świadczeń socjalnych. Należy jednak zauważyć, że są także kraje, w których kwota ta jest równa 0 - są to Bułgaria i Węgry.

\subsection{Wzrost kwoty wolnej od podatku a kondycja polskiej gospodarki}

W październiku 2015 roku Trybunał Konstytucyjny (TK), kwestionując brak waloryzacji kwoty wolnej od podatku uznał, że zmiany w tym zakresie są konieczne. Według TK kwota wolna od podatku powinna gwarantować obywatelowi egzystencję choćby na minimalnym poziomie, co określono na kwotę 6549,12 zł. Podniesienie kwoty wolnej od podatku spowoduje oszczędność dla indywidualnego podatnika o 51,91 zł miesięcznie - 622,92 zł rocznie. Polska ma jeden z najniższych wskaźników tej kwoty, która dodatkowo nie była od wielu lat waloryzowana. Czy proponowane rozwiązania są jednak korzystne?

Kancelaria Prezydenta Andrzeja Dudy, w listopadzie ubiegłego roku, przesłała do Sejmu projekt, który jednorazowo proponuje podwyższenie kwoty wolnej od podatku z 3091 zł do 8000 zł. Miesięczna kwota zmniejszająca zaliczkę na podatek dochodowy wzrosłaby z 46,33 zł do 120 zł. Podatnik zyskałby więcej o 73,67 zł (według KPRP, koszt zaproponowanych zmian oszacowano na $15,58 \mathrm{mld}$ zł). Z ekonomicznego punktu widzenia propozycja prezydenta wydaje się być nierealną. Tak gwałtowne podniesienie kwoty wolnej od podatku spowodowałaby przekroczenie przez Polskę limitu deficytu 3\% PKB. Z kolei Ministerstwo Finansów proponuje, by podwyżkę rozłożyć na lata i stopniowo dochodzić do kwoty obiecanej przed wyborami - co roku podnosić kwotę wolną od podatku o 1000 zł, by dojść do kwoty 8000 zł w 2021 roku. W takim wariancie podatnik w pierwszym roku zmian zyskałby 13,67 zł miesięcznie. Przez kolejne cztery lata kwota zmniejszająca zaliczkę na podatek będzie zwiększać się o 15 zł w każdym roku. Resort wylicza, że w pierwszym roku obowiązywania wyższej kwoty wolnej od podatku, koszty wyniosłyby 4 mld zł (-0,2\% PKB), w 2018 roku -8 mld zł (-0,4\% PKB), a w 2019 roku -12 mld zł (-0,5\% PKB) (Ministerstwo Finansów, 2016). Proponowane zmiany kwoty wolnej od podatku z ok. 3 tys. do 8 tys. zł pokazano na rysunku 1 . 
Rysunek 1. Proponowana modyfikacja kwoty wolnej od podatku przez Kancelarię Prezydenta i Ministerstwo Finansów

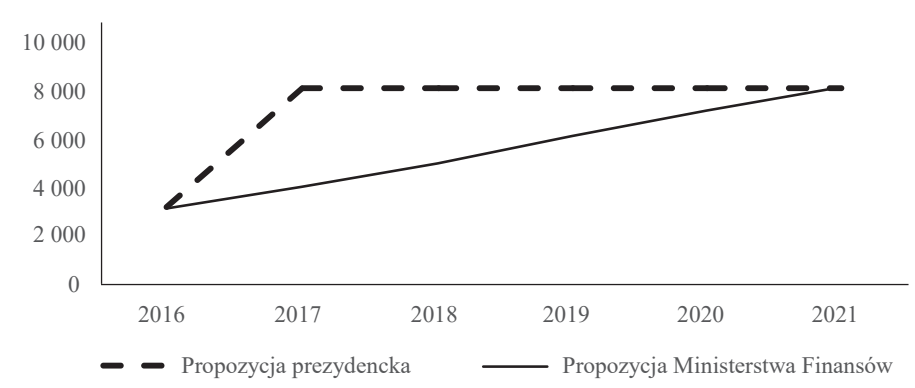

Źródło: opracowanie własne na podstawie danych Kancelarii Prezydenta i Ministerstwa Finansów.

\subsection{Podwyższenie kwoty wolnej od podatku i skutki dla działalności organizacji pożytku publicznego oraz gospodarki}

Rozważając zagadnienie podwyższenia kwoty wolnej od podatku, można przypuszczać, że zmniejszenie kwoty odprowadzanego podatku dochodowego, biorąc pod uwagę prosty rachunek ekonomiczny, może doprowadzić do obniżenia wpływów z 1\%, na działalność organizacji ze statusem OPP. 1\%, od nadwyżki kwoty powyżej 3091 zł jest wartością większą niż 1\% od nadwyżki kwoty powyżej 8000 zł. Zależność ta wystąpi oczywiście przy założeniu, że rząd podnosząc kwotę wolną od podatku nie podejmie dodatkowych kroków w celu zabezpieczenia działań organizacji III sektora (w tym zakresie). Na obecnym etapie nie można oszacować dokładnej wartości obniżonych wpływów, gdyż rozważania o podwyższeniu kwoty wolnej od podatku trwają, stąd nie sposób ich obliczyć, w odniesieniu do rzeczywistych, obowiązujących ustaleń legislacyjnych.

„Podwyższenie kwoty wolnej od podatku może spowodować spadek dochodów budżetu państwa nawet o ponad 20 mld zł, co może skutkować koniecznością drastycznego ograniczenia wydatków (...), a tym samym zmniejszy możliwość zaspokajania potrzeb mieszkańców” (za portalem Onet Biznes), pośrednio także przez ograniczenie dotacji dla organizacji OPP, tym samym wpływając na ich mniejszą sprawczość i możliwość niesienia pomocy. Należy pamiętać jakie funkcje pełnią organizacje pozarządowe w społeczeństwie i gospodarce. Przede wszystkim stanowią istotny element demokracji i społeczeństwa obywatelskiego oraz sprawują funkcję pomocniczą, uzupełniając rolę państwa. Dążą do wypełnienia luk w publicznym systemie zdrowia, edukacji, usług socjalnych czy kultury i dlatego ich istnienie jest tak istotne dla poprawiania jakości życia obywateli i zapewniania im dóbr oraz usług, adekwatnych do ich potrzeb, dostosowanych do lokalnej sytuacji (za portalem ngo.pl). Nie bez wpływu na gospodarkę pozostanie też ograniczenie funkcji ekonomicznych (zob. tab. 4) organizacji III sektora, co może być spowodowane zmniejszonymi wpływami z $1 \%$. 
Tabela 4. Funkcje ekonomiczne organizacji III sektora

\begin{tabular}{|c|c|}
\hline $\begin{array}{c}\text { Funkcja } \\
\text { ekonomiczna }\end{array}$ & Opis funkcji \\
\hline Zatrudnienie & $\begin{array}{l}\text { sektor pozarządowy daje pracę; w krajach Europy Zachodniej wskaźnik ten jest dość wysoki: } \\
\text { w Belgii czy Holandii osiąga ok. 10-14\% wszystkich zatrudnionych; w typowej organizacji po- } \\
\text { zarządowej w Polsce zatrudniającej stały, płatny personel praca w fundacji lub stowarzyszeniu } \\
\text { jest podstawowym źródłem utrzymania dla połowy pracowników }\end{array}$ \\
\hline Dostarczanie usług & $\begin{array}{l}\text { podobnie jak podmioty komercyjne i instytucje administracji publicznej, organizacje świadczą } \\
\text { rozmaite usługi, dotyczy to zwłaszcza usług o charakterze socjalnym (np. zdrowotnych) lub usług } \\
\text { publicznych (np. edukacyjnych) }\end{array}$ \\
\hline $\begin{array}{l}\text { Pilnowanie } \\
\text { wykorzystania dóbr } \\
\text { publicznych }\end{array}$ & $\begin{array}{l}\text { organizacje pełnią funkcję strażnika dóbr publicznych, zarządzanych przez administrację, } \\
\text { np. oświetlenie uliczne, porządek publiczny, czyste środowisko; organizacje pilnują, aby korzy- } \\
\text { stano z nich w sposób odpowiedni i aby dostęp do nich był równy oraz by nie zostały one wyeks- } \\
\text { ploatowane (tę ich funkcję - szczególnie w sferze ekologii - określa się czasem jako promowanie } \\
\text { zrównoważonego rozwoju) }\end{array}$ \\
\hline $\begin{array}{l}\text { Proponowanie } \\
\text { innowacyjnych } \\
\text { rozwiązań }\end{array}$ & $\begin{array}{l}\text { organizacje pozarządowe proponują często zupełnie niekonwencjonalne, nowe formy działania; } \\
\text { nowatorstwo podejmowanych przez nie działań polega przede wszystkim na zdolności tworzenia } \\
\text { procedur, wzorców zachowań i modeli organizacyjnych w naturalny sposób wyrastających z oto- } \\
\text { czenia, w którym są wprowadzane }\end{array}$ \\
\hline $\begin{array}{l}\text { Zmniejszanie } \\
\text { wydatków na } \\
\text { świadczenia } \\
\text { społeczne }\end{array}$ & $\begin{array}{l}\text { III sektor to w znacznej mierze organizacje działające na rzecz włączenia do życia społecznego } \\
\text { grup marginalizowanych, pracujące z tzw. trudnymi klientami, osobami w dużym stopniu zależ- } \\
\text { nymi od państwowych instytucji pomocy społecznej; z perspektywy budżetu państwa działalność } \\
\text { organizacji oznaczać może więc mniejsze wydatki na świadczenia społeczne, mniejsze zatrudnie- } \\
\text { nie w szarej strefie czy niższe wydatki na ochronę zdrowia }\end{array}$ \\
\hline $\begin{array}{l}\text { Pośrednie wsparcie } \\
\text { dla rozwoju } \\
\text { gospodarczego }\end{array}$ & $\begin{array}{l}\text { tworzenie „kapitału społecznego”- III sektor buduje kapitał społeczny, a więc pośrednio wspiera } \\
\text { rozwój gospodarczy }\end{array}$ \\
\hline
\end{tabular}

Źródło: opracowanie własne na podstawie Raportu z Badań 2015 Stowarzyszenia Klon/Jawor; Adamiak, Charycka, Gumkowska (2016), s. 54-55.

Szacowane przez Ministerstwo Finansów wpływy z 1\% podatku za 2014 rok, dla wszystkich przeszło 8 tys. OPP, wynosiły 557,6 mln zł (Ministerstwo Finansów, 2015, s. 2). Ta wysoka kwota obrazuje skalę korzyści, jakie dzięki niej realizują OPP, pełniąc rolę pomocniczą dla państwa, które nie zawsze i nie do końca radzi sobie z oddolną, podstawową pomocą swoim obywatelom.

$\mathrm{Z}$ danych zaprezentowanych na rysunku 2 możemy wnioskować, że skala kwoty z 1\% podatku dochodowego jest niebagatelna i z pewności służy bezpośrednio na ,realizację dobroczynności”. Można zatem postawić tezę, że państwo próbując wdrożyć nowe rozwiązania (w istocie swojej słuszne), zapomniało o żywotnym interesie pewnych grup zawodowych czy społecznych. Według bardzo ostrożnych szacunków, polski sektor pozarządowy jest co najmniej pięciokrotnie słabszy ekonomicznie niż przeciętny sektor w krajach zachodnich (Gliński, 2002, s. 23). Ważkość tej sytuacji i powagę problemu dostrzegli ostatnio senator Antoni Szymański, czy społecznik i menedżer Tomasz Marzec - zgodnie twierdząc, że należy zwrócić uwagę, iż w OPP jest zatrudnionych na etacie kilkanaście tysięcy osób, dla których praca ta stanowi główne miejsce zatrudnienia (GUS, 2016, s. 5) i utrzymania (za oświadczeniem złożonym przez senatora Antoniego Szymańskiego na 22. posiedzeniu Senatu, 7.07.2016 r., skierowanym do Prezesa Rady Ministrów Beaty Szydło). Organizacje o statusie OPP budują ośrodki, rozwijają działalność, zdarza się, że zaciągają wielomilionowe kredyty na budowę ośrodków rehabilitacyjnych, integracyjnych czy sportowych. Kredyty te były zaciągane, ponieważ zdolność kredytowa podmiotów 
Rysunek 2. Środki finansowe otrzymane przez OPP w latach 2003-2015 (mln zł)

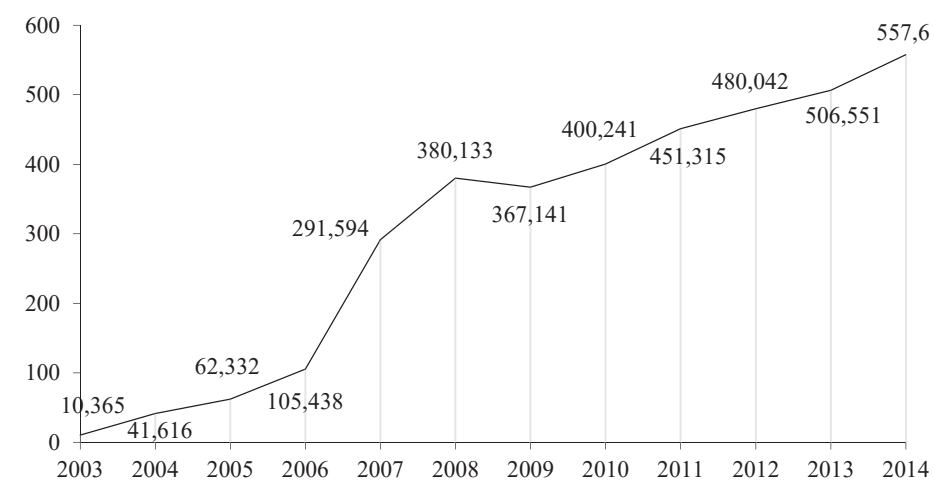

Źródło: opracowanie własne na podstawie danych Ministerstwa Finansów.

je zaciągających poparta była wpływami z 1\%. W przypadku planowanych zmian, a co za tym idzie problemów ze spłatą zadłużenia, dla banków niewystarczającym będzie argument, że to zmiany wprowadzone przez rząd przyczyniły się do braku pieniędzy w danej organizacji. Czy zatem rząd nie powinien przed wprowadzeniem wyżej wskazanych zmian, zastanowić się najpierw nad zmianami w prawie podatkowym? Uzasadnione byłoby przeprowadzenie konsultacji ze środowiskiem pozarządowym, choćby uzyskanie w tej sprawie opinii Rady Działalności Pożytku Publicznego, będącej ustawowym organem opiniodawczo-doradczym ministra właściwego do spraw zabezpieczenia społecznego.

Dane zaprezentowane w tabeli 5 ukazują 10 polskich (spośród 8 tys.) organizacji ze statusem organizacji pożytku publicznego, które za rok 2014 otrzymały najwyższe kwoty, w ramach $1 \%$ podatku od osób fizycznych. Liczby te są w stanie tylko w niewielkim stopniu przybliżyć skalę dobra, jakie dzieje się za sprawą OPP. Należy pamiętać, że pozyskane w ten sposób środki mogą być wydane wyłącznie na prowadzenie działalności pożytku publicznego, a więc na

Tabela 5. Organizacje ze statusem pożytku publicznego, które otrzymały najwyższe kwoty z 1\% należnego podatku dochodowego od osób fizycznych, z rozliczenia za 2014 rok

\begin{tabular}{|l|l|c|}
\hline Numer KRS & \multicolumn{1}{|c|}{ Nazwa organizacji ze statusem organizacji pożytku publicznego } & Kwota w zł \\
\hline 0000037904 & Fundacja Dzieciom „Zdążyć z pomocą” & 136189516,87 \\
\hline 0000186434 & Fundacja Pomocy Dzieciom Niepełnosprawnym „Słoneczko” & 20716552,76 \\
\hline 0000270809 & Avalon - Bezpośrednia Pomoc Niepełnosprawnym & 15791702,80 \\
\hline 0000207472 & Fundacja „Rosa” & 10392917,53 \\
\hline 0000270261 & Fundacja Studencka „Młodzi-Młodym” & 8264421,17 \\
\hline 0000050135 & Dolnośląska Fundacja Rozwoju Ochrony Zdrowia & 6353187,59 \\
\hline 0000174486 & Fundacja Anny Dymnej Mimo Wszystko & 5327369,42 \\
\hline 0000086210 & Fundacja „Na Ratunek Dzieciom z Chorobą Nowotworową” & 5168613,46 \\
\hline 0000266644 & Fundacja Serce Dziecka Im. Diny Radziwiłłowej & 5146888,46 \\
\hline 0000091141 & Fundacja „Nasza Przyszłość” & 5059480,34 \\
\hline
\end{tabular}

Źródło: Departament Podatków Dochodowych Ministerstwa Finansów (2015). 
dobroczynność, kulturę, edukację, zapobieganie patologiom, sztukę. Informacje na co zostały spożytkowane środki są publiczne i transparentne oraz podlegają wielu kontrolom instytucji państwowych. Daje to obraz wielkości środków, które dzięki zaangażowaniu OPP wracają wprost do społeczeństwa. Nie sposób wyobrazić sobie funkcjonowania nowoczesnego państwa bez sektora organizacji pozarządowych, wśród których, że względu na przekazywanie środków finansowych na pomoc i działania oddolne, pierwszeństwo wiodą organizacje ze statusem OPP - to one pomagają setkom i tysiącom osób ubogich, nieradzącym sobie z życiem codziennym, wykluczonym i marginalizowanym, prowadząc działalność charytatywną, kulturalną, edukacyjną, sportową, integracyjną, readaptacyjną i wiele innych.

\section{Podsumowanie}

W przypadku podniesienia kwoty wolnej od podatku, nad pytaniami o alternatywną konstrukcję wsparcia dla OPP, jej planowanego kształtu, sposobu ustanowienia i konsultowania ze stronami zainteresowanymi czy innymi, alternatywnymi rozwiązaniami, powinni pochylić się rządzący. Rząd, przed podjęciem jakiejkolwiek decyzji winien przyjrzeć się szczególnie wnikliwie ich skutkom. Jeśli tego nie uczyni może się okazać, że wiele z 8 tys. OPP nie przetrwa. Z pewnością nie jest dobrym rozwiązaniem tworzenie instrumentów, które są korzystne pozornie, krótkofalowo. Idea wzbogacenia portfela obywateli na rzecz odebrania im realnej pomocy od organizacji OPP, nie wydaje się do końca słuszna. Należy pamiętać, że sektor pozarządowy pełni funkcję pomocniczą dla jednostek samorządowych i rządowych, realnie wspomagając państwo - można tu przytoczyć chociażby przykład wielu tysięcy zakupionych sprzętów medycznych czy wyposażonych oddziałów szpitalnych przez Wielką Orkiestrę Świątecznej Pomocy. Aby obniżać podatki z korzyścią dla gospodarki i bez zachwiania równowagi finansów państwa, powinno się proporcjonalnie ograniczyć wydatki. Zastanawiając się nad wprowadzeniem mechanizmu obniżania kwoty wolnej od podatku wraz ze wzrostem dochodów, trzeba byłoby pomyśleć o gruntownej reformie polskiego systemu podatkowego i systemu pomocy społecznej, który na obecnym etapie nie wydaje się być przygotowany do takich zmian.

Bieżąca propozycja MF, by koszty podwyżki kwoty wolnej rozłożyć w czasie, wydaje się być godna rozważenia. Pozwoli łagodniej wejść w proces przejściowy, da czas na podjęcie newralgicznych decyzji, skonstruowanie sposobów dla rekompensat utraconych dochodów dla OPP, pozwoli na opracowanie instrumentów dla sfinansowania ich z innych źródeł. Wzrost kwoty wolnej od podatku z pewnością wpłynie na zwiększoną konsumpcję, większe wpływy z akcyzy, a w konsekwencji na wzrost gospodarczy i wyższe wpływy podatkowe, jednak zrealizowany na proponowanych obecnie zasadach może skończyć się fiaskiem.

\section{Literatura}

Adamiak, P., Charycka, B., Gumkowska, M. (2016). Kondycja sektora organizacji pozarzadowych w Polsce 2015. Raport z Badań. Warszawa: Stowarzyszenie Klon/Jawor.

Arystoteles. Polityka. W: Arystoteles. Dzieła wszystkie, t. VI (2001). Warszawa: Wydawnictwo Naukowe PWN.

Gliński, P. (2006). Style działań organizacji pozarzadowych w Polsce. Grupy interesu czy pożytku publicznego? Warszawa: Instytut Filozofii i Socjologii Polskiej Akademii Nauk. 
Gliński, P. (red.) (2002). Samoorganizacja społeczeństwa polskiego: Trzeci sektor. Warszawa: Wydawnictwo Instytutu Filozofii i Socjologii PAN.

Główny Urząd Statystyczny (2016), Działalność stowarzyszeń i podobnych organizacji społecznych, fundacji, społecznych podmiotów wyznaniowych oraz samorzadu gospodarczego i zawodowego w 2014 - wyniki wstepne. Warszawa: GUS.

Gorlach, K. (red.) (1996). Oblicza społeczeństwa. Uwagi o „czwartym” obszarze społecznym. Kraków. Uniwersytet Jagielloński.

Hudson, M. (1997). Bez zysków i strat. Sztuka kierowania organizacjami sektora pozarządowego. Warszawa: Fundusz Współpracy/Cooperation Fund.

Leś, E. (2000). Od filantropii do pomocniczości: studium porównawcze rozwoju i działalności organizacji społecznych. Warszawa: Dom Wydawniczy ELIPSA.

Majchrzak, M. (red.) (2015). Finanse Ekonomii Społecznej, Szczecin-Poznań: Wydawnictwo Wyższej Szkoły Bankowej w Poznaniu.

Ministerstwo Finansów (2015). Informacja dotyczaca kwot 1\% należnego podatku dochodowego od osób fizycznych przekazanych organizacjom pożytku publicznego z rozliczenia za 2014. Warszawa: MF.

Ministerstwo Finansów (2016). Aktualizacja Programu Konwergencji na 2016 r., która jest czéścia Wieloletniego Planu Finansowego Państwa na lata 2016-2019. Warszawa: MF.

Ministerstwo Pracy i Polityki Społecznej. Pobrano z: http://www.pozytek.gov.pl/Opublikuj,sprawozdanie,w,bazie,742. html (1.08.2016).

Mucha, M. (red.) (2011). Organizacje pożytku publicznego. Fundacje i Stowarzyszenia w roli podatnika. Wrocław: UNIMEX Oficyna Wydawnicza.

Oświadczenie złożone przez Senatora Antoniego Szymańskiego na 22. posiedzeniu Senatu, w dniu 7 lipca 2016 r., skierowane do Prezesa Rady Ministrów Beaty Szydło. Warszawa.

Pieńkowska, D. (2015). Ekonomia społeczna - podstawowe informacje. Polsko-Amerykański Fundusz Pożyczkowy Inicjatyw Obywatelskich. Pobrano z: www.pafpio.pl (15.09.2015).

Piotrowski, B. (2010). Ksztaltowanie się polityki społecznej w Polsce - od okresu międzywojennego po dzień dzisiej$s z y$, opublikowano w portalu rynekpracy.org. Pobrano z: http://rynekpracy.org/x/543528?action=table.SetPageSize $\& \mathrm{ci}=$ podstrona_komentarze $\& \mathrm{did}=601764 \& \mathrm{fid}=57424 \&$ table 8008 -pageSize $=3 \&$ tableId $=8008 \#$ komentarze (1.08.2016).

Po co sa organizacje pozarzadowe (NGO)? Pobrano z: http://fakty.ngo.pl/rola-ngo (3.04.2017).

Ustawa z 6 kwietnia 1984 r. o fundacjach (Dz.U. nr 21, poz. 97).

Ustawa z 7 kwietnia 1989 r. Prawo o stowarzyszeniach (Dz.U. nr 20, poz. 104).

Ustawa z dnia 24 kwietnia 2003 r. o działalności pożytku publicznego i o wolontariacie (Dz.U. 2014, poz. 1118).

Ustawa z dnia 29 lipca 2005 r. o obrocie instrumentami finansowymi (Dz.U. nr 183, poz. 1538).

Ustawy z dnia 26 lipca 1991 r. o podatku dochodowym od osób fizycznych (Dz.U. nr 80, poz. 350 ze zm.).

Za portalem Onet Biznes. Pobrano z: http://biznes.onet.pl (5.08.2016).

Za portalem wyborcza.biz. Pobrano z: http://wyborcza.biz/biznes/0,0.html?disableRedirects=true (5.08.2016).

\section{Cytowanie}

Lewandowska, A. (2016). Analiza i ocena wpływu wzrostu kwoty wolnej od podatku na kondycję finansową organizacji ze statusem pożytku publicznego. Współczesne Finanse. Teoria i Praktyka, 1 (1), 47-59. DOI: 10.18276/ wf.2016.1-05. 